\title{
Korrektur zum Reisebericht Felix Kleins
}

Frau Dr. R. Tobies vermutete, da $B$ mir bei der Publikation des Reiseberichts Kleins aus dem Jahre 1902 (NTM, N.S., Vol.5,1997, Nr.4, S. 245-252) ein Lesefehler unterlaufen ist. Eine nochmalige Überprüfung der Quelle ergab, daß das Wort „Zeitraum“ (Seite 248, Zeile 2) durch das Wort „Zutrauen“ zu ersetzen ist.

Reinhard Siegmund-Schultze

\section{Liebig-Wöhler-Freundschafts-Preis an Jan W. van Spronsen}

Johannes W. van Spronsen, chemistry educator; b. The Hague, The Netherlands, Feb. 7, 1928; s. Willem and Nicolasina (Van Dokkum) van S.; m. Susanna Van Brouwershaven, Aug 3, 1949; 1 child, Nicolasina Jeanne Johanna. Grad., Tech. U., 1946; PhD, U. Leiden, 1969. Docent Gymnasium Alkmaar, 1954-84, Electrotech. Sch., Amsterdam, 1953-63, U. Utrecht, 1960-85.

Author: A History of the Periodic System of Elements, 1969; editor: Nobel Prize Topics in Chemistry, 1965; Contbr. articles to profl. jours.

Recipient Silver and Aureate medal Paris Soc. Arts and Scis. Lettres, Gillis prize Royal Flemish Acad. Sci., Dexter award Am. Chem. Soc., Sarton medal U. Gent.

Mem. Stichting Orgelcentrum (pres. 1978-95), Royal Netherlands Chem. Soc. (chmn. hist. commn. 1959-, Yan Marum medal). Fedn. European Chem. Socs. (chmn. working party on history of chemistry 1976-93, sec. 1995-). Netherland Soc. for History of Medicine, Math., Phys. Scis. and Tech. (sec. 1978-88, Minerva medal), German Soc. for History of Medicine, Math., Phys. Scis. and Tech. (corr. mem.), Royal Instn. Gt. Britain, Soc. for History of Alchemy and Chemistry, Royal Flemish Chem. Soc. (sect. history of chemistry) Gesellschaft Deutscher Chemiker (sect. history of chemistry, delegate of the Société Arts, Sciences, Lettres, Paris). lands.

Office:Royal Netherlands Chem. Soc., Burnierstraat 1, NL-2596 HV The Hague, The Nether-

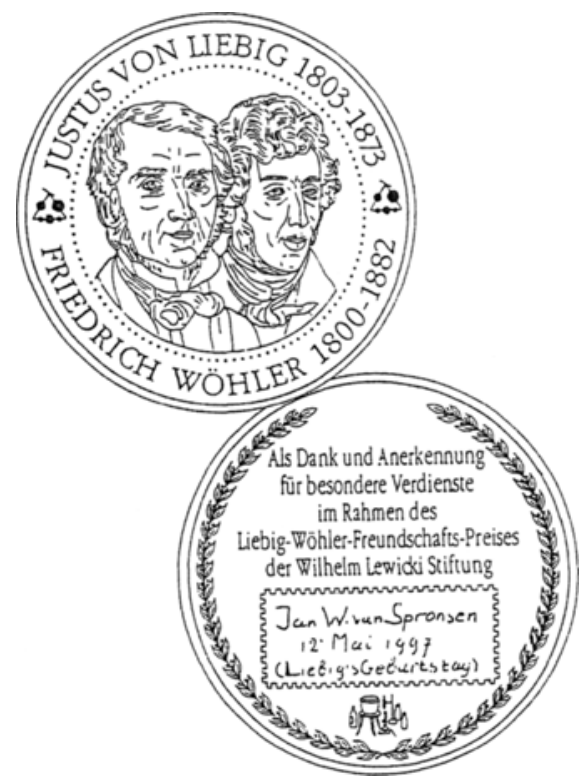

